\title{
Towards a New Definition of Blended Learning
}

\author{
Johannes C Cronje \\ Cape Peninsula University of Technology \\ Johannes.cronje@gmail.com \\ DOI: 10.34190/EJEL.20.18.2.001
}

\begin{abstract}
Most current definitions of blended learning refer to a blend of online and face-to-face instruction. It seems that few authors notice the irony that the definition of blended learning does not include the concept of learning at all. The problem with these definitions is that they are devoid of theory and thus lead to trial-and-error research. This paper argues that the definition of blended learning should be built around learning theory and should refer to a blend of direct instruction and learning-by-doing. The paper reports on research conducted to validate a model that puts behavioural and constructivist learning at right angles and considers if the two can occur simultaneously. The model is then placed in the context of a framework of knowledge management and from there a definition is derived that includes context, theory, methodology and technology.
\end{abstract}

Keywords: Blended learning; constructivism, behaviourism, objectivism, learning theory, context

\section{Introduction}

Arguably one of the most common definitions of the term Blended Learning is that of Graham who expresses it as learning systems that "combine face-to-face instruction with computer mediated instruction" (Graham, 2006, p.41). Variations of this definition abound also in papers published in this journal throughout the years (Charbonneau-Gowdy, 2018; Banditvilai, 2016; Soeiro, de Figueiredo and Ferreira, 2012; Onguko, 2014; Tshabalala, Ndeya-Ndereya and van der Merwe, 2014; Gynther, 2016; Nakayama, Mutsuura and Yamamoto, 2016; Kintu and Zhu, 2016; Nortvig, Petersen and Hattesen Balle, 2018; Uziak et al., 2018; Jakab, Ševčík and Grežo, 2017). Very few authors, however, explore any of the other elements that may form part of the blend in blended learning as defined in the earlier definition by Marcy Driscoll, who presents a much more refined definition that includes:

- To combine or mix modes of Web-based technology (e.g., live virtual classroom, self-paced instruction, collaborative learning, streaming video, audio, and text) to accomplish an educational goal.

- To combine various pedagogical approaches (e.g., constructivism, behaviorism, cognitivism) to produce an optimal learning outcome with or without instructional technology.

- To combine any form of instructional technology (e.g., videotape, CD-ROM, Web-based training, film) with face-to-face instructor-led training.

- To mix or combine instructional technology with actual job tasks in order to create a harmonious effect of learning and working (Driscoll, 2002, p.54).

This paper seeks to refine the common definition by specifically commenting on those pedagogical approaches that may be connected to learning theory. The problem driving this position paper is that the current definitions of blended learning concentrate on the blend and ignore the learning.

\section{Background and literature survey}

The origin of the term blended learning is generally traced back to a 1999 press release by EPIC learning in Atlanta (Friesen, 2012), who points out that, from the outset the term has been plagued by ambiguity, and concludes: "Blended learning, in other words, is almost any combination of technologies, pedagogies and even job tasks. It includes some of the oldest mechanical media (e.g., film) and theories of learning (e.g., behaviourism), as well as the newest" (Friesen, 2012, p.2). In 2006 Graham deplores the ambiguity of the term in that:

"these positions suffer from the problem that they define [blended learning] so broadly that they encompass virtually all learning systems. One would be hard pressed to find any learning system [or combination of methods] that did not involve multiple instructional methods and multiple delivery media" (Graham, 2006, p.4). 
After an extensive analysis of the various definitions of the term Friesen proposes that "Blended learning' designates the range of possibilities presented by combining Internet and digital media with established classroom forms that require the physical co-presence of teacher and students" (Friesen, 2012, p.1).

\subsection{The missing ingredient}

The problem with Friesen's definition, however, is that it still does not acknowledge learning, unlike a definition in a previous issue of this journal which does, as it points out that: "The concept of blended learning is derived from two words, blend and learning. The word blend means combining things and learning denotes an assimilation of new knowledge" (Tshabalala, Ndeya-Ndereya and van der Merwe, 2014, pp.102-103).

The definitions of blended learning provided in this journal by authors who use the term in the titles of their work are equally diffuse. Table 1 provides an overview of definitions provided by such authors in the period from 2012 to 2018. The table has been arranged in order of pedagogical complexity, from no definition through technology-driven definitions, to pedagogical and strategic definitions.

Table 1 shows that a literature survey conducted in 2018 indicates that there still is very little consensus as to a universal definition of the term Blended learning (Nortvig, Petersen and Hattesen Balle, 2018). Another author (Charbonneau-Gowdy, 2018) simply refers to examples of what she considers to be blended learning. She requires the reader to develop an understanding of how she uses the term from a description of the project discussed in the article. The majority of authors rely on the classic combination of face-to-face and technology to frame their definitions, although there seems to be a taxonomy of complexity ranging from a simple statement of technologies to an acknowledgement of teaching and learning, context, pedagogy and finally value (Uziak et al., 2018; Nakayama, Mutsuura and Yamamoto, 2016; Kintu and Zhu, 2016; Onguko, 2014; Gynther, 2016). Some authors extend the metaphor of the blend to that of a recipe, by referring to ingredients and method(Banditvilai, 2016; Tshabalala, Ndeya-Ndereya and van der Merwe, 2014). Only one article goes as far as seeing blended learning as a strategy, although, ironically these authors do not provide a definition for blended learning at all (Soeiro, de Figueiredo and Ferreira, 2012).

From the analysis of articles in past issues of this journal it can be seen then that there is no clear definition of blended learning that places the focus on learning. What does become clear though is that, in their writing, the authors of these papers are fully aware that the complexities of blended learning go far beyond deciding between face-to-face and technology-mediated contact.

In considering the relationship between the blend and the learning, or the "combining of things (...and the) assimilation of knowledge" (Tshabalala, Ndeya-Ndereya and van der Merwe, 2014, p.102) it is necessary to consider two of the key arguments in our field - (1) the so-called "Clark-Kozma debate" (Clark, 1994; Kozma, 1994) and (2) the No significant difference phenomenon (Russell, 1999). Richard E Clark (1994) has argued since 1983 that the medium of instruction does not influence the quality of learning. He uses the now famous grocery truck analogy saying that the medium of instruction will no more influence the quality of learning than a delivery truck would influence the nutritional value of the food it delivers. Kozma (1994) however argues that certain affordances of technology may well enable forms of learning that others do not - in other words, you cannot drive a grocery truck to the moon. Tom Russell, in support of Clark, presents a bibliography of 355 academic works that indicate no significant differences (NSD) in student outcomes between various modes of delivering education (Russell, 1999).

Along these lines some authors argue that "despite the failure of some variables to show as significant factors to blended learning outcomes, learners showed a high affinity to engage in blended learning; which accounts for learner attitudes being contributors to learner satisfaction and intrinsic motivation" (Kintu and Zhu, 2016, p.192). Others draw specific attention to the affective domain. In a passionate conclusion Soeiro, de Figueiredo and Ferreira argue that "beyond what is often described as the coldness of technology, educators and students can help each other find technology-supported contexts that never existed and where people can learn (together) to listen with their hearts" (2012, p.348). 
Table 1: Definitions of 'Blended learning' in EJEL articles

\begin{tabular}{|c|c|c|c|}
\hline Category & Definition & Author & Comment \\
\hline No definition & $\begin{array}{l}\text { "there has not been complete } \\
\text { agreement among researchers about } \\
\text { the precise definition or meaning of the } \\
\text { term 'blended learning"" }\end{array}$ & $\begin{array}{l}\text { (Nortvig, Petersen and } \\
\text { Hattesen Balle, 2018, } \\
\text { p.47) }\end{array}$ & $\begin{array}{l}\text { Authors conducted a literature } \\
\text { survey based on a search for "e- } \\
\text { learning" OR "online learning" OR } \\
\text { "blended learning" OR "hybrid } \\
\text { learning" and concluded that no } \\
\text { clear definition existed. }\end{array}$ \\
\hline Hybrid & $\begin{array}{l}\text { "Massive Open Online Courseware } \\
\text { (MOOC's) or their hybrids, so-called } \\
\text { Blended Learning Programs" }\end{array}$ & $\begin{array}{l}\text { (Charbonneau-Gowdy, } \\
2018, \text { p.56) }\end{array}$ & $\begin{array}{l}\text { Author uses MOOC as an example } \\
\text { of what she means by Blended } \\
\text { Learning and provides no formal } \\
\text { definition. }\end{array}$ \\
\hline \multirow[t]{5}{*}{$\begin{array}{l}\text { Face-to-face } \\
\text { and } \\
\text { technology }\end{array}$} & $\begin{array}{l}\text { "...platforms are also used for delivery } \\
\text { and tracking of blended learning, i.e. a } \\
\text { combination of traditional (face-to-face) } \\
\text { and on-line resources" }\end{array}$ & (Uziak et al., 2018, p.1) & \multirow{2}{*}{$\begin{array}{l}\text { These two authors use the most } \\
\text { basic definition that relies simply on } \\
\text { the dimensions of contact and } \\
\text { technology to deliver (and track) } \\
\text { learning materials. No mention is } \\
\text { made of the actual learning that } \\
\text { may occur. }\end{array}$} \\
\hline & $\begin{array}{l}\text { "...blended learning, which consists of } \\
\text { face-to-face sessions and learning } \\
\text { materials that are supported by } \\
\text { information communication technologies } \\
\text { (ICT)" }\end{array}$ & $\begin{array}{l}\text { (Nakayama, Mutsuura } \\
\text { and Yamamoto, 2016, } \\
\text { p.43) }\end{array}$ & \\
\hline & $\begin{array}{l}\text { "The design in this study involves a } \\
\text { transition from traditional face-to-face } \\
\text { teaching-learning to blended learning } \\
\text { with technology" }\end{array}$ & $\begin{array}{l}\text { (Kintu and Zhu, 2016, } \\
\text { p.181) }\end{array}$ & $\begin{array}{l}\text { These authors include the terms } \\
\text { teaching and learning. }\end{array}$ \\
\hline & $\begin{array}{l}\text { "In this paper, blended learning is } \\
\text { defined as a deliberate combination of } \\
\text { self-directed study of offline content } \\
\text { deployed on tablets, with occasional } \\
\text { face-to-face meetings, moderated } \\
\text { through instructor-led sessions. This } \\
\text { definition takes into consideration } \\
\text { access to offline professional } \\
\text { development (PD) content on tablets } \\
\text { combined with teachers' face-to-face } \\
\text { interactions with their peers and } \\
\text { instructors referred to as professional } \\
\text { development tutors (PDTs). JiFUNzeni } \\
\text { blended learning approach emphasizes } \\
\text { the use of appropriate technologies for } \\
\text { each context based on the contextual } \\
\text { realities". }\end{array}$ & (Onguko, 2014, p.78) & $\begin{array}{l}\text { In addition to a clear description of } \\
\text { what was done this author adds the } \\
\text { dimensions of appropriateness and } \\
\text { context. }\end{array}$ \\
\hline & $\begin{array}{l}\text { "Blended learning courses integrate } \\
\text { online with face-to-face instruction in a } \\
\text { planned, pedagogically valuable } \\
\text { manner, and do not just combine but } \\
\text { trade-off face-to-face with online activity } \\
\text { (or vice versa)" (Vignare, } 2007, \text { p.38). }\end{array}$ & (Gynther, 2016, p.21) & $\begin{array}{l}\text { This author recognises pedagogy } \\
\text { and value. }\end{array}$ \\
\hline \multirow[t]{2}{*}{ Ingredients } & $\begin{array}{l}\text { "The article underscores the concept } \\
\text { that many "ingredients" can comprise a } \\
\text { blended learning model, including } \\
\text { instructor-delivered content, e-learning, } \\
\text { webinars, conference calls, live or online } \\
\text { sessions with instructors, and other } \\
\text { media and events, for example, } \\
\text { Facebook, e-mail, chat rooms, blogs, } \\
\text { podcasting, Twitter, YouTube, Skype } \\
\text { and web boards" }\end{array}$ & $\begin{array}{l}\text { (Banditvilai, 2016, } \\
\text { p.223) }\end{array}$ & \multirow[t]{2}{*}{$\begin{array}{l}\text { These authors list methods of } \\
\text { delivery as well as platforms used } \\
\text { for such delivery, much as a recipe } \\
\text { would have "ingredients" and a } \\
\text { method. }\end{array}$} \\
\hline & $\begin{array}{l}\text { "the mixture of traditional delivery } \\
\text { including: lectures, group discussions, } \\
\text { apprenticeships and experiential } \\
\text { learning, together with e-learning } \\
\text { methods, which accommodate various } \\
\text { learning needs of a diverse audience in } \\
\text { a variety of subjects" }\end{array}$ & $\begin{array}{l}\text { (Tshabalala, Ndeya- } \\
\text { Ndereya and van der } \\
\text { Merwe, 2014, pp.102- } \\
\text { 103) }\end{array}$ & \\
\hline Strategy & $\begin{array}{l}\text { "...we were exploring pedagogical } \\
\text { participatory strategies, personal and } \\
\text { collaborative, in a blended- learning } \\
\text { environment supported by Moodle" }\end{array}$ & $\begin{array}{l}\text { (Soeiro, de Figueiredo } \\
\text { and Ferreira, 2012, } \\
\text { p.339) }\end{array}$ & $\begin{array}{l}\text { Although these authors do not } \\
\text { provide a clear definition of blended } \\
\text { learning they refer to pedagogy as } \\
\text { well as strategy. }\end{array}$ \\
\hline
\end{tabular}


More comprehensively though authors argue for a sensitivity to the context in which learning takes place: "thus in a context where there is lack of access to electricity, Internet is not guaranteed, and schools lack basic amenities including clean and safe learning spaces, learning materials such as textbooks and facilities such as desks, blended learning must be redefined with consideration of the contextual realities" (Onguko, 2014, p.78). In some contexts it could even be argued that technological solutions are better than face-to-face: "on the other hand, it illustrates how deaf students who do not want to expose themselves can benefit from the experience of community learning afforded by pedagogical strategies and tools that could never exist face-toface" (Soeiro, de Figueiredo and Ferreira, 2012, p.347).

If there is to be no significant difference in learner performance, regardless of the mode of delivery then it holds that, in developing blended learning alternatives one should look rather at the theoretical underpinnings of teaching and learning than at the delivery mechanisms. One could therefore argue that a definition of blended learning needs not be too specific in defining exactly what delivery medium is used. It is the context, rather than the meaning, that makes a difference. A definition of blended learning should focus on learning.

\subsection{Two dimensions of learning}

Over time behaviourism and constructivism have evolved as two major, opposing dimensions of learning (Lowrey, 2013). The binary opposing nature of the two paradigms has been outlined by many authors, including Cronje (2006, p.390).

\begin{tabular}{|c|c|c|}
\hline Category & Objectivism & Constructivism \\
\hline $\begin{array}{l}\text { The real } \\
\text { world... }\end{array}$ & $\begin{array}{l}\text { has entities that can be categorized on } \\
\text { the basis of their properties and } \\
\text { relations. }\end{array}$ & $\begin{array}{l}\text { is structured by our individual minds on } \\
\text { the basis of our interactions (this limits } \\
\text { what we can know about the real } \\
\text { world). }\end{array}$ \\
\hline Reality is... & $\begin{array}{l}\text { fully and explicitly structured in a } \\
\text { way that is shared by all who perceive } \\
\text { it. Because of this commonality, } \\
\text { reality can be modeled and shared } \\
\text { with others. }\end{array}$ & $\begin{array}{l}\text { local (personal) to ourselves in a } \\
\text { universe of multiple realities. Our } \\
\text { realities are modeled by the way in } \\
\text { which we personally construct them. }\end{array}$ \\
\hline $\begin{array}{l}\text { Symbols } \\
\text { are... }\end{array}$ & $\begin{array}{l}\text { representations of reality, and are } \\
\text { only meaningful to the degree that } \\
\text { they correspond to reality. }\end{array}$ & $\begin{array}{l}\text { products of culture that are used to } \\
\text { construct reality. }\end{array}$ \\
\hline $\begin{array}{l}\text { The human } \\
\text { mind... }\end{array}$ & $\begin{array}{l}\text { processes abstract symbols and } \\
\text { fashions them so that they mirror } \\
\text { nature. }\end{array}$ & $\begin{array}{l}\text { perceives and interprets the world by } \\
\text { creating symbols. }\end{array}$ \\
\hline $\begin{array}{l}\text { Human } \\
\text { thought is.. }\end{array}$ & $\begin{array}{l}\text { symbol-manipulation and is } \\
\text { independent of the human organism.. }\end{array}$ & $\begin{array}{l}\text { is imaginative, and develops out of } \\
\text { perception, sensory } \\
\text { experiences, and social interaction. }\end{array}$ \\
\hline Meaning.. & exists objectively and independently & is a construction that is the end result of \\
\hline
\end{tabular}

Figure 1: Contrasting views of Objectivism and Constructivism (Cronje, 2006, p.390)

The view of behaviourism/objectivism and constructivism as opposites was particularly strong in the 1990s. There were various calls for a move towards constructivism (Jonassen, 1991; Davis et al., 1993). More recently these two "opposing" dimensions have been researched specifically as they contribute both to face-to-face and online learning (Weegar and Pacis, 2012). It has been shown that, while early computer-based training programmes were primarily behaviourist in their design, "the use of technology in online courses has slowly shifted the theoretical balance from behaviorism to constructivism due to the increased use of educational technologies" (Weegar and Pacis, 2012, p.17).

More recently there is an increased call for the integration of behaviourist and constructivist principles (Elen, 2017). The problem with a model of linear opposition between the two paradigms is that, as the one goes up, the other goes down. If the balance is shifting from the one to the other then, at some stage, there will be a position that is neither behaviourist nor constructivist. Nevertheless it is argued that "often instructors are 
choosing to utilize a combination of these two learning styles in an effort to best meet the learning styles for all students" (Weegar and Pacis, 2012, p.17).

To overcome this problem of a false dichotomy Cronje (2006) proposed a two-by-two matrix plotting the two extremes at right angles as shown in Figure 2. The resultant matrix contains four quadrants, construction, which is high in constructivist and low in behaviourist/objectivist elements, injection which is high in behaviourism but low in constructivism, where the "combination of these two learning styles" (Weegar and Pacis, 2012, p.17) is highest, and the immersion quadrant, which is low in overt evidence of either, and where "it is safe to conclude that the majority of our learning occurs informally" (Shipley, 2017, p.118).

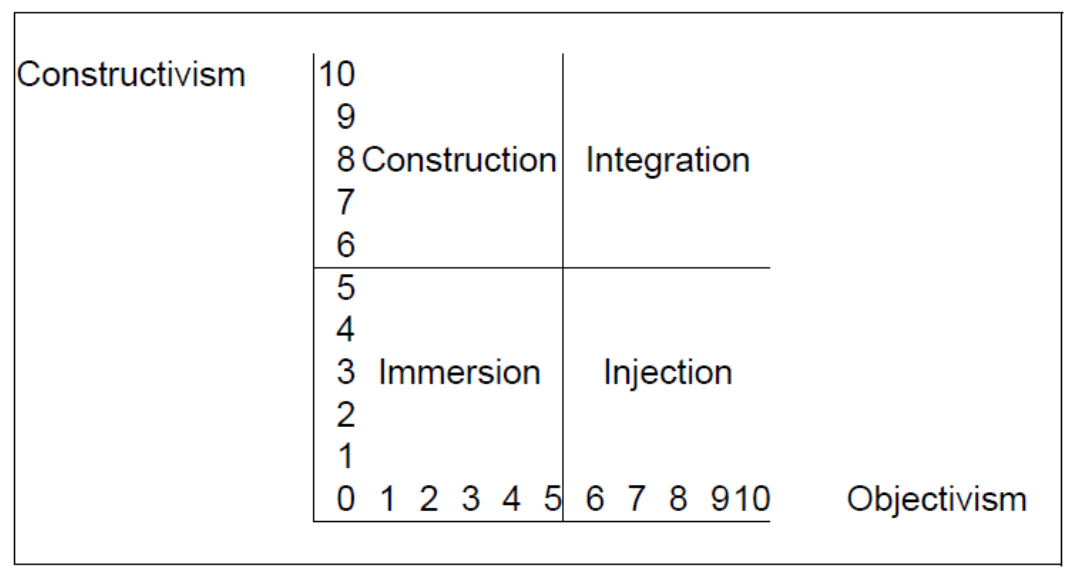

Figure 2: The integration of two learning paradigms (Cronje, 2006, p.392)

The model has subsequently been tested by Elander, (2012) who found that it was indeed possible to identify courses that were high in both behaviourist and constructivist elements, as is shown in Figure 3 . Elander demonstrated that the majority of instructional designers worked mainly in an objectivist/behaviourist paradigm, but that there were substantially more designers who took an integrated, and therefore blended approach, than those who worked in the immersion or construction quadrants only.

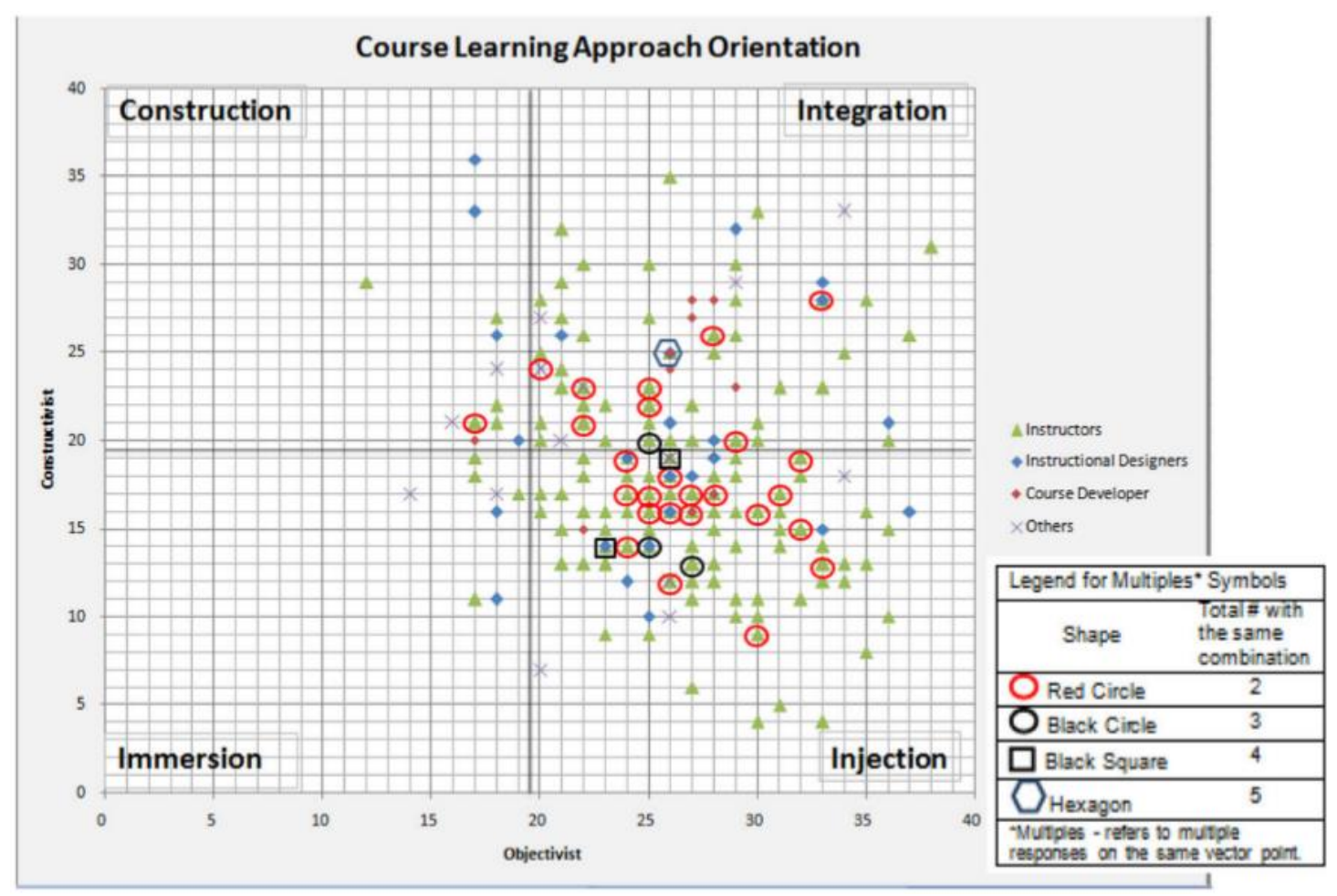

Figure 3: Four quadrants of blended learning demonstrated (Elander and Cronje, 2016, p.399) 


\section{Discussion: Elements of the blend}

In response to Clark (1994), Kozma (1994) and Russell (1999) the selection of a specific medium is subservient to context, and the dimension of face-to-face or at-a-distance is a sub-set of context. Thus I argue that it is context that drives the decision of what and how to blend. The Cynefin framework (Figure 4) provides a good initial point of departure to establish context.

For Known knowledge cause and effect are repeatable, perceivable and predictable and legitimate best practice and standard operating procedures have been established. In this case direct (behaviourist) instruction is the most appropriate. Using problem-based learning in this field would lead to frustration and a waste of time (Clark, Kirschner and Sweller, 2012) the blended learning model would therefore concentrate on Instruction. In a contact environment this would amount to lectures and demonstrations and in a distance environment books (physical or digital) or (instructional) videos.

For Complex knowledge cause and effect are only retrospectively coherent, and pattern recognition is required. Here a constructivist approach is appropriate. Learners learn how to make sense of complexity. It is important to recognise that constructivist learning is more about learning to learn than about learning to acquire skills - as was pointed out in an earlier issue of this journal: "knowledge construction is highly exhibited and significant factors in this include learner interactions and management of workload" (Kintu and Zhu, 2016, p.192). This is the quadrant of abductive reasoning.

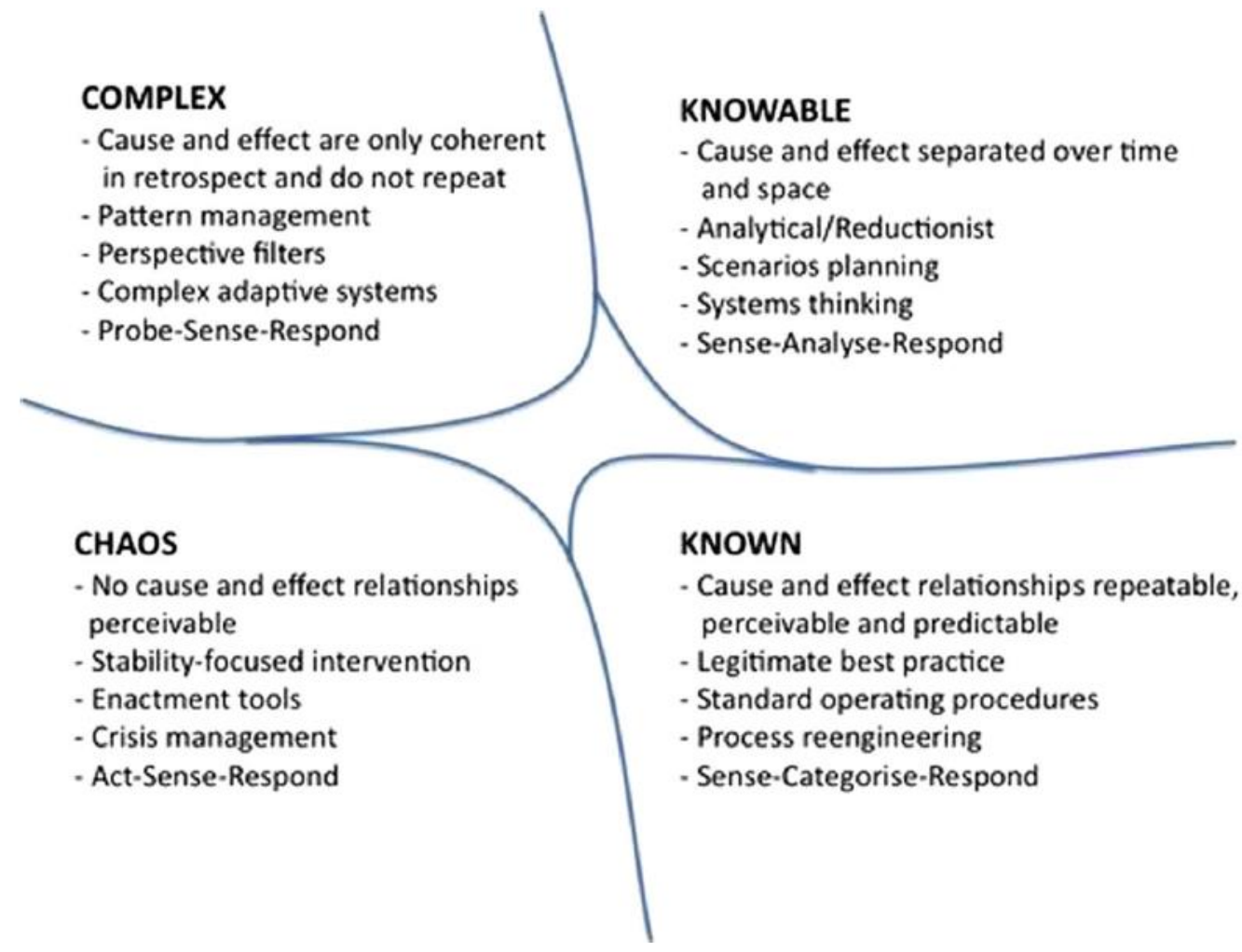

Figure 4: The Cynefin framework (Kurtz and Snowden, 2003, p.464)

Construction tasks, problem-based learning and open-ended learning environments would be appropriate here. In a low-technology environment physical puzzles would be useful and in a high-technology environment spreadsheets and other information-processing tools would be recommended.

In the Knowable domain that calls for analytical and reductionist thinking with cause and effect separated over time an Integrated use of behaviourist and constructivist learning would be appropriate. This is the domain of puzzles rather than problems. Puzzles have solutions known to the instructor but not to the learners, while problems may have endless solutions. The aim in this quadrant is to teach systems thinking. In a contact environment this is where discussions and debates are likely and in a distance environment it is the domain of chat groups and bland discussion forums. 
The Chaos domain is the domain of experience. There is no perceived cause and effect relationship and interventions are aimed at regaining stability. Traditionally this is known as "being thrown into the deep end" or Immersed. In this quadrant there is no evidence of planned intervention of either a behavioural or constructivist nature. Yet this is where Shipley (2017) argues that most learning takes place. This is the domain of the field-trip, the experiential learning and the apprenticeship. In this context teaching is notably absent and learning is incidental and serendipitous. The technology involved here is the logbook, and the blog, and the methodological focus should be on assessment rather than instruction.

\section{Conclusion and recommended definition}

Thus far this paper has shown that, although in the early uses of the term Blended learning, homage was paid to dimensions of learning theory and pedagogy, the majority of definitions are restricted to mentioning a mixture of face-to-face and web-based instruction. This paper argues that more attention should be paid to Driscoll's second bullet point: "To combine various pedagogical approaches (e.g., constructivism, behaviorism, cognitivism) to produce an optimal learning outcome with or without instructional technology" (2002, p.54).

To this end Cronje's (2006) integrated model is proposed as a framework for designing blended learning. The framework resonates strongly with Kurtz and Snowden's (2003) Cynefin framework and in fact each quadrant can be mapped directly from the one model to the other. From this a blended learning decision matrix can be developed that would resemble Table 2.

Table 2: Blended learning decision matrix

\begin{tabular}{|l|l|l|l|}
\hline $\begin{array}{l}\text { Context (Kurtz \& } \\
\text { Snowden) }\end{array}$ & Theory (Cronje) & Methods & Technologies \\
\hline Known & Injection & $\begin{array}{l}\text { Tutorial } \\
\text { Drill }\end{array}$ & $\begin{array}{l}\text { Lecture } \\
\text { Book } \\
\text { Video }\end{array}$ \\
\hline Complex & Construction & $\begin{array}{l}\text { Construction } \\
\text { Exploration }\end{array}$ & $\begin{array}{l}\text { Open-ended learning environments } \\
\text { Construction kits and tools } \\
\text { Spreadsheets }\end{array}$ \\
\hline Knowable & Integration & $\begin{array}{l}\text { Puzzle } \\
\text { Discussion } \\
\text { Debate }\end{array}$ & $\begin{array}{l}\text { Games } \\
\text { Discussion tools }\end{array}$ \\
\hline Chaos & Immersion & $\begin{array}{l}\text { Experience } \\
\text { Field trip } \\
\text { Apprenticeship }\end{array}$ & $\begin{array}{l}\text { Blogs } \\
\text { Logbooks } \\
\text { Assessment tools }\end{array}$ \\
\hline
\end{tabular}

Table 2 is by no means exhaustive but serves as an example of how decision-making could take place around identifying an optimal blend of learning methodologies and technologies.

From the above discussion, it becomes clear a definition of blended learning that is based on the dimensions of face-to-face and technology-mediated instruction, does not provide an adequate theoretical underpinning for such decisions. A definition of blended learning should include context, theory, method and technology, which is why I propose the following definition of blended learning:

The appropriate use of a mix of theories, methods and technologies to optimise learning in a given context.

\section{References}

Banditvilai, C., 2016. Enhancing students' language skills through blended learning. Electronic Journal of e-Learning, 14(3), pp.220-229.

Charbonneau-Gowdy, P., 2018. Beyond stalemate : seeking solutions to challenges in online and blended learning programs. Electronic Journal of e-Learning, 16(1), pp.56-66.

Clark, R.E., 1994. Media will never influence learning. Educational technology research and development, 42(2), pp.21-29.

Clark, R.E., Kirschner, P.A. and Sweller, J., 2012. Putting students on the path to learning the case for fully guided instruction. American Educator, 36(March), pp.6-11.

Cronje, J.C., 2006. Paradigms regained : toward integrating objectivism and constructivism in instructional design and the learning sciences. Educational Technology Research and Development, 54(4), pp.387-416.

Davis, N.T., Jo McCarty, B., Shaw, K.L. and Sidani-Tabbaa, A., 1993. Transitions from objectivism to constructivism in science education. International Journal of Science Education, 15(6), pp.627-636.

Driscoll, M., 2002. Blended learning: let's get beyond the hype. E-learning, 1(4), pp.1-4. 
Elander, K.R., 2012. Merging paradigms: The integration of objectivist and constructivist approaches in university settings. [online] ProQuest Dissertations and Theses. Capella University. Available at: <https://search.proquest.com/docview/1035351588?accountid=8144>. [Accessed 6 Nov 2019]

Elander, K. and Cronje, J.C., 2016. Paradigms revisited: a quantitative investigation into a model to integrate objectivism and constructivism in instructional design. Educational Technology Research and Development, 64(3), pp 389 - 405.

Elen, J., 2017. Implications: cherishing the middle ground. In:L. Lin and J.M. Spector, eds. 2017. The Sciences of Learning and Instructional Design. Routledge, pp.85-93.

Friesen, N., 2012. Defining blended learning. Learning Spaces, [online] (August), p.10. Available at: https://www.normfriesen.info/papers/Defining Blended Learning NF.pdf. [Accessed 6 Nov 2019]

Graham, C.R., 2006. Blended learning systems. In C.J. Bonk and Graham, eds. 2012.The handbook of blended learning, Hoboken, NJ: Wiley E Sons. pp.3-21.

Gynther, K., 2016. Design Framework for an adaptive MOOC enhanced by blended learning:. Electronic Journal of eLearning, 14(1), pp.15-30.

Jakab, I., Ševčík, M. and Grežo, H., 2017. Model of higher GIS education. Electronic Journal of e-Learning, 15(3), pp.220234.

Jonassen, D.H., 1991. Objectivism versus constructivism: do we need a new philosophical paradigm? Educational technology research and development, 39(3), pp.5-14.

Kintu, M.J. and Zhu, C., 2016. Student characteristics and learning outcomes in a blended learning environment intervention in a Ugandan University, Mountains of the Moon University and Vrije Universiteit Brussel. The Electronic Journal of e-Learning, 14(3), pp.181-195.

Kozma, R., 1994. Will media influence learning? Reframing the debate. Educational technology research and development. [online] Available at: <http://link.springer.com/article/10.1007/BF02299087> [Accessed 1 Jul. 2016].

Kurtz, C.F. and Snowden, D.J., 2003. The new dynamics of strategy: sense-making in a complex and complicated world. IBM systems journal, 42(3), pp.462-483.

Lowrey, A.E., 2013. Behaviorism vs. constructivism. Available at:: <https://athenaeum.libs.uga.edu/handle/10724/29910>. [Accessed 6 Nov. 2019]

Nakayama, M., Mutsuura, K. and Yamamoto, H., 2016. Student's reflections on their learning and note-taking activities in a blended learning course. Electronic Journal of e-Learning, 14(1), pp.43-53.

Nortvig, A.-M., Petersen, A.K. and Hattesen Balle, S., 2018. A literature review of the factors influencing e-learning and blended learning in relation to learning outcome, student satisfaction and engagement. The Electronic Journal of eLearning, 16(1), pp.46-55.

Onguko, B., 2014. JiFUNzeni: A Blended Learning Approach for Sustainable Teachers' Professional Development. Electronic Journal of e-Learning, 12(1), pp.77-88.

Russell, T.L., 1999. The no significant difference phenomenon: a comparative research annotated bibliography on technology for distance education: as reported in 355 research reports, summaries and papers. Raleigh, NC: North Carolina State University.

Shipley, P., 2017. Coaching and evidence-based learning. Journal of Community Safety and Well-Being, 2(3), pp.116-118.

Soeiro, D., de Figueiredo, A.D. and Ferreira, J.A.G., 2012. Mediating diversity and affection in blended learning: a story with a happy ending. Electronic Journal of e-Learning, 10(3), pp.339-348.

Tshabalala, M., Ndeya-Ndereya, C. and van der Merwe, T., 2014. Implementing blended learning at a developing university: obstacles in the way. Electronic Journal of e-Learning, 12(1), pp.101-110.

Uziak, J., Oladiran, M.T., Lorencowicz, E. and Becker, K., 2018. Students' and instructor's perspective on the use of blackboard platform for delivering an engineering course. Electronic Journal of e-Learning, 16(1), pp.1-15.

Vignare, K., 2007. Review of literature, blended learning: using ALN to change the classroom-will it work. In:AG Picciano \& CD Dziuban (Red.), Blended learning: research perspectives (pp 37-63). Needham, MA: Sloan Consortium.

Weegar, M.A. and Pacis, D., 2012. A comparison of two theories of learning-behaviorism and constructivism as applied to face-to-face and online learning. In: Proceedings, e-leader conference, Manila. 